\title{
Maintenance therapy for FLT3-ITD-mutated acute myeloid leukemia
}

\section{Andreas Burchert}

Department of Internal Medicine, Hematology, Oncology and Immunology, Philipps University Marburg and University Hospital Giessen and Marburg, Campus Marburg, Marburg, Germany

Haematologica 2021

Volume 106(3):664-670

\section{Correspondence:}

ANDREAS BURCHERT

burchert@staff.uni-marburg.de

Received: August 25, 2020.

Accepted: January 7, 2021.

Pre-published: January 21, 2021.

https://doi.org/10.3324/haematol.2019.240747

(C)2021 Ferrata Storti Foundation

Material published in Haematologica is covered by copyright. All rights are reserved to the Ferrata Storti Foundation. Use of published material is allowed under the following terms and conditions:

https://creativecommons.org/licenses/by-nc/4.0/legalcode. Copies of published material are allowed for personal or internal use. Sharing published material for non-commercial purposes is subject to the following conditions:

https://creativecommons.org//icenses/by-nc/4.0/legalcode, sect. 3. Reproducing and sharing published material for commercial purposes is not allowed without permission in writing from the publisher.

\section{ABSTRACT}

F LT3-ITD is a constitutively activated variant of the FLT3 tyrosine kinase Ireceptor. Its expression in acute myeloid leukemia (AML) is associated with a poor prognosis. Due to this, the development of tyrosine kinase inhibitors (TKI) blocking FLT3-ITD became a rational therapeutic concept. This review describes key milestones in the clinical development of different FLT3-specific TKI with a particular focus on FLT3-TKI maintenance therapy in remission after allogeneic hematopoietic stem cell transplantation (HCT). Recent evidence from randomized trials using sorafenib in FLT3-ITD mutated AML provided a proof of concept that targeted post-HCT maintenance therapy could become a new treatment paradigm in AML.

\section{Why FLT3 as a therapeutic target in acute myeloid leukemia?}

AML is a clonal stem cell malignancy. Although AML prognosis is governed by genomic features, ${ }^{1-3}$ therapeutic targeting of recurrently mutated genes is a complex task. ${ }^{4}$ For example, while mutations in epigenetic regulator genes such as DNMT3A or ASXL1 are recurrently detected in $\mathrm{AML}^{5}$ and are linked to a dismal prognosis, 3,6 the same mutations are also very frequently found in hematopoietic stem cells of healthy elderly individuals with 'clonal' (so-called 'age-related hematopoiesis' or CHIP/ARCH-associated mutations). ${ }^{7,8}$ Thus, although $\mathrm{ARCH}$ mutations seem to be instrumental drivers of clonal progression towards $\mathrm{AML}^{5,8}$ their detection in AML per se does not qualify them as therapeutic targets in AML. ${ }^{9}$ This is because the expression of mutant oncoproteins is therapeutically exploitable only if their inhibition induces differentiation, restricts growth, or reduces viability of the AML bulk. A perfect target oncoprotein in AML is the constitutively activated FLT3 receptor tyrosine kinase which results from mutations in the FMS-like tyrosine kinase 3 (FLT3) gene. FLT3 mutations emerge very late during AML pathogenesis., ${ }^{3,10}$ They are found in approximately 30\% of all AML patients and can be either FLT3-tyrosine kinase point mutations (FLT3-TKD) or FLT3 internal tandem duplication mutations (FLT3-ITD). ${ }^{11}$ Only FLT3-ITD mutations are associated with a poor outcome in AML. ${ }^{12,13}$ FLT3-TKD and FLT3-ITD cause uncontrolled signaling through the ERK-signaling, PI3-kinase signaling, and, in the case of FLT3-ITD, also STAT5-signaling, ${ }^{14}$ and drive stem cell transformation. ${ }^{15,16}$ By 'hijacking' the signal transduction machinery of AML cells, FLT3 oncoproteins generate a strong dependence on FLT3-signaling pathways to sustain survival. As a result, AML cells undergo apoptosis in vitro and in vivo when FLT3 signaling output is blocked by a TKI. ${ }^{17,18}$ Dependence on FLT3 oncoproteins provided the biological rationale for the clinical development of FLT3 inhibitors in FLT3mutated AML (reviewed by Kindler et al..$^{18}$ and Daver et al. ${ }^{19}$ ).

In this review, I will discuss evidence that illustrates the value of FLT3-TKI when used as maintenance therapy in remission after allogeneic hematopoietic stem cell transplantation (HCT) compared with its use outside the context of a HCT.

The main characteristics and approval status of currently developed FLT3 inhibitors are shown in Table 1.

\section{A long road for FLT3-TKI in acute myeloid leukemia}

In spite of the preclinical data showing a promising activity of FLT3 inhibitors in FLT3-mutated AML, it has proven difficult to translate these preclinical results into 
Table 1. Important characteristics of FLT3 kinase inhibitor therapy in acute myeloid leukemia.

\begin{tabular}{|c|c|c|c|c|c|}
\hline & $\begin{array}{c}\text { FLT3-ITD IC }[\mathrm{nM}] \\
\text { (MV4-11 cellular proliferation } \\
\text { inhibition) }{ }^{20,21}\end{array}$ & $\begin{array}{l}\text { Relevant off target } \\
\text { activity }\end{array}$ & $\begin{array}{l}\text { Approval(s) } \\
\text { by FDA/EMA }\end{array}$ & $\begin{array}{l}\text { Current clinical } \\
\text { development }\end{array}$ & $\begin{array}{c}\text { Efficacy } \\
\text { (level } 1 \text { evidence) }\end{array}$ \\
\hline Midostaurin (PKC-412) & 12 & $\begin{array}{l}\text { Multikinase inhibitor } \\
\text { (PKN1, TBK1, JAK3 etc.) }\end{array}$ & $\begin{array}{l}\text { First-line } \\
\text { FLT3-mutated AML } \\
\text { and ASM }\end{array}$ & $\begin{array}{l}\text { Maintenance } \\
\text { post HCT }\end{array}$ & OS benefit \\
\hline Sorafenib & 3.2 & $\begin{array}{c}\text { Multikinase inhibitor } \\
\text { (VEGFR, PDGFR } \beta, \text { BRAF etc.) }\end{array}$ & $\begin{array}{l}\text { Renal cancer } \\
\text { liver cancer }\end{array}$ & $\begin{array}{l}\text { Maintenance } \\
\text { post HCT }\end{array}$ & $\begin{array}{l}\text { PFS and OS } \\
\text { benefit }\end{array}$ \\
\hline Crenolanib & 2.1 & $\begin{array}{l}\text { Selective TKI } \\
(\mathrm{PDGFR} \alpha / \beta)\end{array}$ & None & & n.a. \\
\hline Quizartinib & 0.56 & $\begin{array}{l}\text { Selective TKI } \\
\text { (KIT) }\end{array}$ & None & Maintenance & OS benefit \\
\hline Gilteritinib (ASP2215) & 0.92 & $\begin{array}{l}\text { Selective TKI } \\
\text { (AXL) }\end{array}$ & r/r-FLT3-mutated AML & Maintenance & OS benefit \\
\hline
\end{tabular}

AXL:AXL receptor tyrosine kinase; ASM: aggressive systemic mastocytosis; EMA: European Medicines Agency; FDA:US Food and Drug Administration; $n$ a : not available; OS: ove all survival; KIT (CD117): stem cell factor receptor; PFS: progression-free survival; r/r: relapsed / refractory; TKI: tyrosine kinase inhibitor; HCT: hematopoietic allogeneic stem cell transplantation.

a clinical benefit in vivo, especially in the monotherapy setting. For example, the first-generation FLT3 and multikinase inhibitor midostaurin failed to induce complete remissions (CR) or even partial remissions (PR) in relapsed or refractory ( $\mathrm{r} / \mathrm{r}$ )-FLT3-mutated AML. ${ }^{23,24}$ Likewise, lestaurtinib, another multitargeted FLT3 TKI, kills FLT3-ITD ${ }^{+}$AML cells in vitro and reduces bone marrow blasts in 5 out of $17 \mathrm{r} / \mathrm{r}$-FLT3-ITD ${ }^{+}$AML patients. However, PR or CR are not achieved with lestaurtinib as monotherapy. ${ }^{25,26}$ In elderly relapsed FLT3-mutated AML patients, lestaurtinib given after chemotherapy did not improve response rates or survival. ${ }^{27}$ In newly diagnosed younger AML with FLT3-activating mutations, lestaurtinib given after first-line induction and consolidation chemotherapy failed to improve either relapse-free survival (RFS) or overall survival (OS) ${ }^{28}$

Sorafenib is a multitargeted TKI that was originally developed as a B-RAF and multi-kinase inhibitor in renal/hepatocellular cancer. However, the compound also shows potent FLT3-ITD inhibitory activity. Intriguingly, in a phase I trial recruiting FLT3-ITD mutated r/r-AML patients ${ }^{29}$ sorafenib monotherapy induced PR and CR. A case series later confirmed activity of sorafenib in $\mathrm{r} / \mathrm{r}-$ FLT3-ITD and also in FLT3-wild-type AML. ${ }^{30-32}$ However, no randomized sorafenib monotherapy trial was ever launched in AML. Intriguingly, when sorafenib monotherapy was given to FLT3-ITD ${ }^{+}$AML patients relapsing after HCT, some cases achieved durable remissions, suggesting a remarkable synergism between proapoptotic FLT3-kinase inhibition and anti-AML immunity through the allogeneic immune system. . $^{32,33}$

The Quantum-R and ADMIRAL trials were the first randomized, placebo-controlled trials to provide evidence that second-generation, FLT3-selective inhibitors (quizartinib and gilteritinib) improved OS (by 2 to 4 months) in r/r-FLT3-mutated AML. ${ }^{34,35}$

Although the potential for clinical efficacy of FLT3-TKI in AML has been clearly demonstrated, in the r/r-AML setting, responses to FLT3-inhibitor monotherapy are usually only temporary. Treatment-emergent FLT3-TKI resistance restricts efficacy regardless of the type of inhibitor used. ${ }^{17,25,32,35-41}$ To address this problem, and find synergistic therapeutic modalities, TKI were integrated into available first-line AML treatments. For example, in the SORMAL trial ${ }^{42}$ and the RATIFY study, ${ }^{43}$ FLT3-TKI were combined with chemotherapy followed by a TKI maintenance phase with either sorafenib or midostaurin. In SORAML, sorafenib led to reduced rates of relapse, progression or death. ${ }^{42}$ In the double blind, randomized RATIFY study, the addition of midostaurin to conventional induction/consolidation chemotherapy followed by 12 months of midostaurin maintenance improved $O S$ in FLT3-mutated AML. ${ }^{43}$

\section{FLT3-TKI maintenance outside the context of allogeneic hematopoietic stem cell transplantation}

Although BCR-ABL and FLT3-ITD drive oncogene dependence, they fail to induce leukemic self-renewal, ${ }^{44,45}$ which explains why FLT3-ITD inhibition alone fails to eliminate leukemic stem cells. In several studies, FLT3TKI were combined with intensive chemotherapy or hypomethylating agents (HMA). ${ }^{28,42,43,46-54}$ Three of these combination therapy trials (which were randomized and placebo-controlled: RATIFY, ${ }^{43}$ SORAML, ${ }^{42}$ and clinicaltrials.gov identifier NCT0037337366) included a TKI maintenance therapy after first-line chemotherapy/TKI induction and consolidation. ${ }^{42,43,46}$ In all three trials, TKI maintenance was discontinued once patients underwent HCT. A post hoc efficacy analysis of the midostaurin-maintenance phase in the RATIFY trial suggested that midostaurin maintenance might not further reduce the probability of relapse, ${ }^{43}$ even though RATIFY was not designed to test this. ${ }^{55}$ In the SORAML study, RFS curves further separated over time, including during the maintenance phase of the trial..$^{42}$ However, once again, the trial could not determine to what extent the sorafenib maintenance phase in particular contributed to the improved RFS.

\section{FLT3-TKI maintenance after allogeneic stem cell transplantation}

With a probability of disease recurrence of $50 \%$ or over, AML relapse remains the most frequent type of treatment failure after HCT, especially in high-risk patients with FLT3-ITD ${ }^{+}$AML. ${ }^{56,57}$ Prognosis of relapsed AML after HCT is generally poor due to a lack of effective treatments. 
Table 2. Trials testing post-hematopoietic stem cell transplantation (HCT) maintenance therapy.

\begin{tabular}{|c|c|c|c|c|c|}
\hline & Clinical trial & $\begin{array}{l}\text { Patients' } \\
\text { characteristics }\end{array}$ & Endpoints & $\begin{array}{l}\text { Clinical trial } \\
\text { register }\end{array}$ & Main result \\
\hline \multicolumn{6}{|c|}{ Post-HCT-TKI maintenance therapy only } \\
\hline $\begin{array}{l}\text { Midostaurin } \\
\text { (PKC-412) }\end{array}$ & $\begin{array}{l}\text { - phase II (RADIUS) } \\
\text { - randomized } \\
\text { - comparator arm: SOC } \\
\text { - open label } \\
\text { Status: completed }\end{array}$ & $\begin{array}{l}\text { - } \mathrm{n}=60 \text { AML } \\
\text { - only FLT3-ITD } \\
\text { - age } \geq 18 \mathrm{y} \text { and } \leq 70 \mathrm{y} \\
\text { - CHR at inclusion } \\
\text { - first CHR only } \\
\text { - maintenance for } 12 \text { months } \\
\text { - treatment started } 28-60 \text { days } \\
\text { post HCT }\end{array}$ & $\begin{array}{l}\text { Primary: } \\
\text { 18-month RFS } \\
\text { Secondary: OS }\end{array}$ & NCT01883362 & No benefit ${ }^{62}$ \\
\hline Sorafenib & $\begin{array}{l}\text { - SORMAIN trial } \\
\text { - phase II } \\
\text { - randomized 1:1 } \\
\text { - arm A: sorafenib } \\
\text { - arm B: placebo } \\
\text { - double blind } \\
\text { - treatment starts } \\
\text { 60-100 days post HCT } \\
\text { - 24 months of therapy } \\
\text { Status: completed }\end{array}$ & $\begin{array}{l}\text { - } \mathrm{n}=83 \text { AML } \\
\text { - only FLT3-ITD } \\
\text { - age } \geq 18 \mathrm{y} \\
\text { - CHR at inclusion } \\
\text { - first or subsequent CHR }\end{array}$ & $\begin{array}{l}\text { Primary: RFS } \\
\text { Secondary: OS }\end{array}$ & DRKS00000591 & $\begin{array}{l}\text { Reduces risk of } \\
\text { relapse and death } \\
(\text { HR } 0.39, P=0.013)^{63}\end{array}$ \\
\hline Sorafenib & $\begin{array}{l}\text { - phase III } \\
\text { - randomized 1:1 } \\
\text { - arm A: sorafenib } \\
\text { - arm B: SOC } \\
\text { - open label } \\
\text { - treatment starts } \\
\text { 30-60 days post HCT } \\
\text { - between 120-150 days of } \\
\text { sorafenib (until d+180 post } \\
\text { HCT) }\end{array}$ & $\begin{array}{l}\text { - n=202 AML } \\
\text { - only FLT3-ITD } \\
\text { - age } \geq 18 \mathrm{y} \\
\text { - CHR prior to HCT and at } \\
\text { study inclusion } \\
\text { - first or subsequent CHR }\end{array}$ & $\begin{array}{l}\text { Primary: } \\
\text { 1-year RFS } \\
\text { Secondary: OS }\end{array}$ & NCT02474290 & $\begin{array}{l}\text { Reduces risk of } \\
\text { relapse and death } \\
\\
\text { 1y and } 2 y \text { RFS: } \\
7 \% / 12.9 \% \text { vs. } \\
24.5 \% / 31.1 \% \\
(P<0.001) \\
\text { OS better } \\
(P=0.025)^{64}\end{array}$ \\
\hline
\end{tabular}

Status: completed

\begin{tabular}{|c|c|c|c|c|c|}
\hline Gilteritinib & $\begin{array}{l}\text { MORPHO trial } \\
\text { (Astellas Pharma) } \\
\text { - phase III, } \\
\text { - randomized } \\
\text { - arm A (experimental): } \\
\text { gilteritinib } \\
\text { - arm B: placebo } \\
\text { - double blind } \\
\text { - treatment for } 24 \text { months } \\
\text { - treatment starts } 60-90 \text { days } \\
\text { post HCT } \\
\text { Status: recruiting }\end{array}$ & $\begin{array}{l}\text { - } \mathrm{n}=346 \text { AML } \\
\text { - only FLT3-ITD } \\
\text { - age } \geq 18 \mathrm{y} \\
\text { - CHR at inclusion } \\
\text { - first CHR only }\end{array}$ & $\begin{array}{l}\text { Primary: RFS } \\
\text { Secondary: OS }\end{array}$ & NCT02997202 & $\begin{array}{l}\text { Results expected } \\
2025\end{array}$ \\
\hline Crenolanib & $\begin{array}{l}\text { - phase II trial (AROG } \\
\text { Pharmac Inc.) } \\
\text { - uncontrolled } \\
\text { - CHR or no CHR after HCT } \\
\text { - open label } \\
\text { - treatment starts 45-90 days } \\
\text { post HCT } \\
\text { Status: recruiting }\end{array}$ & $\begin{array}{l}\text { - n=48 AML } \\
\text { - FLT3-ITD and/or TKD D } 835 \\
\text { mutation } \\
\text { - age } \geq 18 \mathrm{y} \\
\text { - stratified into CHR vs. } \\
\text { no CHR patients }\end{array}$ & $\begin{array}{l}\text { Primary: PFS } \\
\text { Secondary: DFS and OS }\end{array}$ & NCT02400255 & $\begin{array}{l}\text { Results expected } \\
2021\end{array}$ \\
\hline \multicolumn{6}{|c|}{ First-line TKI plus chemo-induction/consolidation followed by TKI maintenance (including after HCT) } \\
\hline Midostaurin & $\begin{array}{l}\text { - phase II, single arm } \\
\text { - uncontrolled } \\
\text { - chemo/mido combination } \\
\text { first-line; maintenance } \\
\text { after chemo }(\mathrm{n}=22) \\
\text { or HCT }(\mathrm{n}=75)\end{array}$ & $\begin{array}{l}\text { - } \mathrm{n}=284 \\
\text { - FLT3-ITD }+ \\
\text { - age } \geq 18 \mathrm{y} \text { and } \leq 70 \mathrm{y} \\
\text { - maintenance for } 12 \text { months } \\
\text { - treatment started } 30-100 \text { days } \\
\text { post HCT }\end{array}$ & $\begin{array}{l}\text { Primary: } \\
\text { EFS } \\
\text { 2. OS }\end{array}$ & NCT01477606 & $\begin{array}{l}\text { Drug is safe } \\
\text { EFS better than in } \\
\text { historical controls } \\
\text { inued on the next page }\end{array}$ \\
\hline
\end{tabular}




\begin{tabular}{|c|c|c|c|c|c|}
\hline & Clinical trial & $\begin{array}{l}\text { Patients' } \\
\text { characteristics }\end{array}$ & Endpoints & $\begin{array}{l}\text { Clinical trial } \\
\text { register }\end{array}$ & Main result \\
\hline Crenolanib & $\begin{array}{l}\text { - phase III trial (AROG } \\
\text { Pharmac Inc.) } \\
\text { - randomized 1:1, } \\
\text { - arm A (experimental): } 7+3 \\
\text { plus crenolanib during } \\
\text { induction/consolidation; } \\
\text { crenolanib as maintenance } \\
\text { - arm B (standard): } \\
\text { TKI: midostaurin } \\
\text { - open label } \\
\text { Status: recruiting }\end{array}$ & $\begin{array}{l}\text { - } \mathrm{n}=510 \text { AML } \\
\text { - FLT3-ITD and/or TKD D } 835 \\
\text { mutation } \\
\text { - age } \geq 18 \mathrm{y} \text { and } \leq 60 \mathrm{y}\end{array}$ & $\begin{array}{l}\text { Primary: EFS } \\
\text { Secondary: OS }\end{array}$ & NCT03258931 & $\begin{array}{l}\text { Results expected } \\
2025\end{array}$ \\
\hline Quizartinib & $\begin{array}{l}\text { - "Quantum first" trial, } \\
\text { phase III (Daiichi } \\
\text { Sankyo Inc.) } \\
\text { - randomized 1:1, } \\
\text { - arm A (experimental): } \\
\text { 7+3 plus quizartinib during } \\
\text { induction/consolidation; } \\
\text { quizartinib as maintenance } \\
\text { - arm B: } 7+3 \text { plus placebo } \\
\text { Status: active, not recruiting }\end{array}$ & $\begin{array}{l}\text { - } \mathrm{n}=539 \\
\text { - FLT3-ITD mutation } \\
\text { - age } \geq 18 \mathrm{y} \text { and } \leq 75 \mathrm{y}\end{array}$ & $\begin{array}{l}\text { Primary: EFS } \\
\text { Secondary: OS }\end{array}$ & NCT02668653 & $\begin{array}{c}\text { Results expected } \\
2022\end{array}$ \\
\hline Gilteritinib & $\begin{array}{l}\text { - phase III trial } \\
\text { (HOVON/AML-SG) } \\
\text { - randomized 1:1 } \\
\text { - arm A (experimental): } \\
7+3 \text { plus gilteritinib } \\
\text { during induction/ } \\
\text { consolidation; } 12 \text { months } \\
\text { gilteritinib as maintenance } \\
\text { - arm B (standard): } \\
\text { TKI: midostaurin } \\
\text { - open label } \\
\text { Status: recruiting }\end{array}$ & $\begin{array}{l}\text { - } \mathrm{n}=768 \text { AML or MDS-EB2 } \\
\text { - FLT3-ITD and/or TKD mutation } \\
\text { - age } \geq 18 \mathrm{y}\end{array}$ & $\begin{array}{l}\text { Primary: EFS } \\
\text { Secondary: } \\
\text { OS, CR rate }\end{array}$ & NCT04027309 & $\begin{array}{c}\text { Results expected } \\
2023\end{array}$ \\
\hline
\end{tabular}

AML: acute myeloid leukemia; chemo: chemotherapy; CR: complete remission; CHR: complete hematologic remission; d: day; EFS: event-free survival; FLT3: fms like tyrosine kinase 3; HR: hazard ratio; ITD: internal tandem duplication; n: number; mido: midostaurin; OS: overall survival; RFS: relapse-free survival; SOC: standard of care;TKD: tyrosine kinase domain;TKI: tyrosine kinase inhibitor; y: years.

Chemotherapy, donor lymphocyte infusion or second HCT only achieve long-term outcomes in around $5 \%$ of cases. 58,59

Intriguingly, sorafenib monotherapy resulted in durable remissions in a small, but nonetheless important proportion of FLT3-ITD ${ }^{+}$AML patients relapsing after HCT . $^{32,33}$ This clinical observation implied that sorafenib might prevent AML relapse after HCT by inhibiting FLT3-ITDdriven AML outgrowth, thereby giving the new immune system more time to elicit immune responses against residual AML blasts. In a murine FLT3-ITD AML model, FLT3ITD inhibition by sorafenib promoted anti-leukemic T-cell immunity by triggering IL-15 secretion. ${ }^{60}$ On the other hand, sorafenib-induced autocrine IL-15 secretion cannot explain the positive results in the SORAML trial since this study mainly included FLT3-ITD AML patients. Indeed, in mice, sorafenib aggravates T-cell mediated allo-immunity independently from FLT3-ITD inhibition. ${ }^{61}$ Taken together, it seems that different mechanisms might contribute to the beneficial effects of sorafenib observed post HCT. A first placebo-controlled post-HCT maintenance therapy trial (the SORMAIN trial) started in 2010 using the multi-kinase and FLT3-TKI sorafenib (see below).

As of today, five randomized controlled clinical trials have investigated whether FLT3 TKI maintenance therapy post HCT improves outcome (Table 2). Three recent randomized trials addressed the value of FLT3-TKI (crenolanib, quizartinib or gilteritinib) in combination with chemotherapy followed by post-HCT TKI maintenance (Table 2), and some of these are ongoing with results expected between 2021 and 2025.

\section{Midostaurin}

In the RADIUS trial, Maziarz et al. randomized 60 FLT3-ITD ${ }^{+}$AML midostaurin versus standard of care (SOC). ${ }^{62}$ This was an open label trial and midostaurin treatment was given for 12 months. The primary out- 
come, RFS, was comparable for midostaurin- and SOCtreated patients. Thus, the RADIUS-trial does not support a role for midostaurin as maintenance drug post HCT in FLT3-ITD-mutated AML.

An uncontrolled phase II study suggested that midostaurin maintenance post HCT was more efficacious than midostaurin maintenance after conventional chemotherapy/midostaurin combination therapy (Table 2). Of interest, only 75 of 134 patients (56\%) ultimately proceeded to post-HCT maintenance, and most of these patients $(59 \%)$ stopped maintenance earlier (after a median of 9 months). ${ }^{49}$

\section{Gilteritinib and crenolanib}

Maintenance trials with gilteritinib and crenolanib are ongoing (Table 2). The placebo-controlled, Astellas-sponsored trial (MORPHO) plans to randomize 346 FLT3mutated AML patients who were transplanted in first complete hematologic remission. Recruited patients will be stratified according to minimal residual disease (MRD) levels post HCT. The MORPHO trial is expected to report results in 2025 .

\section{Sorafenib}

Evidence is available from two recently published randomized trials: 1) the placebo controlled SORMAIN trial (recruitment period 2010-2015); ${ }^{63}$ and 2) an open label phase III trial from China (recruitment period 2015$2018)^{64}$ evaluating whether sorafenib maintenance post HCT improves progression-free survival (PFS) and OS in FLT3-ITD ${ }^{+}$AML.

In SORMAIN, 83 patients were recruited. The primary endpoint, RFS, was significantly better with sorafenib. After a median follow-up of 41.8 months in SORMAIN, median RFS was not reached with sorafenib versus 30.9 months with placebo (HR 0.39, 95\%CI: 0.18-0.85; $P=0.013){ }^{63}$ During the first two years after randomization, the risk of relapse or death was reduced by $75 \%$ (HR 0.25, $P=0.002) .{ }^{63}$ In the Chinese phase III trial, 202 patients were randomized to receive sorafenib versus placebo. The median follow-up duration is 21.3 months. ${ }^{64}$ The 2-year leukemia-free survival was $78.9 \%$ versus 56.6\% (HR 0.37, 95\% CI: 0.22-0.63; $P<0.0001$ ), which is comparable to that in the SORMAIN trial. At 24 months, OS was higher with sorafenib versus placebo in both the SORMAIN trial $(90.5 \%$ vs. $66.2 \%$; HR $0.24,95 \%$ CI: $0.08-$ $0.74 ; P=0.007)$ and the phase III trial $(82.1 \%$ vs. $68.0 \%$, HR 0.48, 95\% CI: 0.27-0.86; $P=0.012$ ).

In both trials, sorafenib was well tolerated because toxicities could be managed with dose reductions without losing efficacy.

An important aspect of the SORMAIN trial were prospectively acquired MRD data. Although based on a relatively small number of patients, data suggest that sorafenib maintenance is especially beneficial for patients who are already in very good remission at the time of transplantation; among MRD patients prior to allo-HCT, there were 0 of 9 relapses with sorafenib versus 5 of 12 relapses with placebo $(P=0.028){ }^{63}$

Because a large number of retrospective studies had pre- viously established that MRD levels prior and post HCT inversely correlate with probabilities of RFS and OS, ${ }^{65,66}$ SORMAIN data lend further support to the notion that achieving MRD-negativity prior to HCT could become an important treatment goal in this high-risk AML subtype. Thus, achievement of low MRD level prior to HCT, such as, for example, through a chemotherapy/ FLT3-TKI combination treatment ${ }^{67}$ (see trials in Table 2), would support the use of sorafenib maintenance post HCT.

\section{Open questions and future directions}

SORMAIN data and the phase III results from Xuan et al. establish TKI maintenance treatment post HCT as a novel and efficacious therapy. ${ }^{63,64}$ Data from these two trials reveal an unprecedented therapeutic potency of an FLT3-kinase inhibitor if applied in the context of CR after HCT. In such a context, FLT3-inhibition could maintain $\mathrm{CR}$ in the vast majority of patients, who would otherwise relapse. In particular, especially patients with no MRD prior to HCT (but also patients with MRD-positivity after HCT) seem to gain great benefit from FLT3-TKI (sorafenib) maintenance. Thus FLT3-TKI treatment in remission might be a clue as to how to significantly improve the detrimental natural course of FLT3-ITD mutated AML. ${ }^{63}$

Many important questions remain. For example, what is the mechanism underlying these potentially curative effects of sorafenib? It should be emphasized once again that sorafenib is a multi-targeted TKI and that its efficacy in AML can be also FLT3-ITD independent, as evidenced by the SORAML trial, which treated mainly FLT3-ITD AML patients. ${ }^{42}$ Results from ongoing randomized TKI maintenance therapy trials will help clarify whether the benefit of FLT3-TKI maintenance is compound (sorafenib)-specific or whether less promiscuous, highly FLT3-specific inhibitors such as gilteritinib or quizartinib offer comparable or even better benefits (Table 2).

Secondly, the optimal duration of maintenance therapy is unclear: 12 months (as in the phase III study) versus 24 months (as in SORMAIN), or potentially even longer. Finally, it will be important to explore whether the concept of targeted maintenance therapy in remission after HCT is generally applicable also to novel, AML-approved signaling inhibitors such as the BCL-2 inhibitor veneto$\operatorname{clax}^{68}$ or the IDH1/2-inhibitors enasidenib/ivosidenib. ${ }^{69,70}$ Recent positive results from maintenance trials using the oral hypomethylating compound CC-486, ${ }^{71}$ azacytidine ${ }^{72}$ or decitabine ${ }^{73}$ demonstrate that maintenance chemotherapy can meaningfully improve OS.

\section{Disclosures}

$A B$ has received research support from Novartis, $B M S$, and $A O P$ Orphan. He has received honoraria and sits on the advisory boards of BMS, AOP Orphan, Pfizer, and Abbvie.

\section{Funding}

$A B$ was supported by the DFG (GRK 2573) and the German Carreras Leukemia Foundation (16R/2019). 


\section{References}

1. Grimwade D, Ivey A, Huntly BJP. Molecular landscape of acute myeloid leukemia in younger adults and its clinical relevance. Blood. 2016;127(1):29-41.

2.Döhner H, Estey E, Grimwade D, et al. Diagnosis and management of AML in adults: 2017 ELN recommendations from an international expert panel. Blood. 2017;129(4):424-447.

3. Papaemmanuil E, Gerstung M, Bullinger L, et al. Genomic classification and prognosis in acute myeloid leukemia. N Engl J Med. 2016;374(23):2209-2221.

4. Tyner JW, Tognon CE, Bottomly D, et al. Functional genomic landscape of acute myeloid leukaemia. Nature. 2018;562(7728): 526-531

5. Shlush LI, Zandi S, Mitchell A, et al. Identification of pre-leukaemic haematopoietic stem cells in acute leukaemia. Nature. 2014;506(7488):328-333.

6. Guryanova OA, Shank K, Spitzer B, et al. DNMT3A mutations promote anthracycline resistance in acute myeloid leukemia via impaired nucleosome remodeling. Nat Med. 2016;22(12):1488-1495.

7. Busque L, Patel JP, Figueroa ME, et al. Recurrent somatic TET2 mutations in normal elderly individuals with clonal hematopoiesis. Nat Genet. 2012;44(11): 1179-1181.

8. Genovese G, Kähler AK, Handsaker RE, et al. Clonal hematopoiesis and blood-cancer risk inferred from blood DNA sequence. N Engl J Med. 2014;371(26):2477-2487

9. Gillies RJ, Verduzco D, Gatenby RA. Evolutionary dynamics of carcinogenesis and why targeted therapy does not work. Nat Rev Cancer. 2012;12(7):487-493.

10. Ley TJ, Mardis ER, Ding L, et al. DNA sequencing of a cytogenetically normal acute myeloid leukaemia genome. Nature. 2008:456(7218):66-72.

11. Nakao M, Yokota S, Iwai T, et al. Internal tandem duplication of the flt3 gene found in acute myeloid leukemia. Leukemia. 1996;10(12):1911-1918.

12. Thiede C, Steudel C, Mohr B, et al. Analysis of FLT3-activating mutations in 979 patients with acute myelogenous leukemia: association with $F A B$ subtypes and identification of subgroups with poor prognosis. Blood. 2002;99(12):4326-4335

13. Brunet S, Labopin M, Esteve J, et al. Impact of FLT3 internal tandem duplication on the outcome of related and unrelated hematopoietic transplantation for adult acute myeloid leukemia in first remission: a retrospective analysis. J Clin Oncol. 2012;30 (7):735-741.

14. Choudhary C, Brandts C, Schwable J, et al. Activation mechanisms of STAT5 by oncogenic Flt3-ITD. Blood. 2007;110(1):370-374 .

15. Kiyoi $\mathrm{H}$, Towatari M, Yokota S, et al. Internal tandem duplication of the FLT3 gene is a novel modality of elongation mutation which causes constitutive activation of the product. Leukemia 1998:12(9):1333-1337.

16. Lee BH, Tothova Z, Levine RL, et al. FLT3 mutations confer enhanced proliferation and survival properties to multipotent progenitors in a murine model of chronic myelomonocytic leukemia. Cancer Cell. 2007;12(4):367-380.

17. Smith CC, Wang Q, Chin C-S, et al. Validation of ITD mutations in FLT3 as a therapeutic target in human acute myeloid leukaemia. Nature. 2012;485(7397):260-263.
18. Kindler T, Lipka DB, Fischer T. FLT3 as a therapeutic target in AML: still challenging after all these years. Blood. 2010;116(24): 5089-5102.

19. Daver N, Kantariian H. FLT3 inhibition in acute myeloid leukaemia. Lancet Oncol. 2017;18(8):988-989.

20.Zarrinkar PP, Gunawardane RN, Crame $\mathrm{MD}$, et al. AC220 is a uniquely potent and selective inhibitor of FLT3 for the treatment of acute myeloid leukemia (AML). Blood. 2009;114(14):2984-2992.

21. Mori M, Kaneko N, Ueno $Y$, et al. Gilteritinib, a FLT3/AXL inhibitor, shows antileukemic activity in mouse models of FLT3 mutated acute myeloid leukemia. Invest New Drugs. 2017:35(5):556-565.

22. Davis MI, Hunt JP, Herrgard S, et al. Comprehensive analysis of kinase inhibitor selectivity. Nat Biotechnol. 2011;29(11): 1046-1051.

23. Stone RM, DeAngelo DJ, Klimek V, et al. Patients with acute myeloid leukemia and an activating mutation in FLT3 respond to a small-molecule FLT3 tyrosine kinase inhibitor, PKC412. Blood. 2005;105(1):54-60.

24. Fischer T, Stone RM, DeAngelo DJ, et al. Phase IIB trial of oral midostaurin (PKC412), the FMS-like tyrosine kinase 3 recepto (FLT3) and multi-targeted kinase inhibitor, in patients with acute myeloid leukemia and high-risk myelodysplastic syndrome with either wild-type or mutated FLT3. J Clin Oncol. 2010;28(28):4339-4345.

25. Smith BD, Levis M, Beran M, et al. Singleagent CEP-701, a novel FLT3 inhibitor, shows biologic and clinical activity in patients with relapsed or refractory acute myeloid leukemia. Blood. 2004;103(10): 3669-3676.

26. Knapper S, Burnett AK, Littlewood T, et al. A phase 2 trial of the FLT3 inhibitor lestaurtinib (CEP701) as first-line treatment for older patients with acute myeloid leukemia not considered fit for intensive chemotherapy. Blood. 2006;108(10):3262-3270

27. Levis M, Ravandi F, Wang ES, et al. Results from a randomized trial of salvage chemotherapy followed by lestaurtinib for patients with FLT3 mutant AML in first relapse. Blood. 2011;117(12):3294-3301.

28. Knapper S, Russell N, Gilkes A, et al. A randomized assessment of adding the kinase inhibitor lestaurtinib to first-line chemotherapy for FLT3-mutated AML. Blood. 2017;129(9):1143-1154

29. Zhang W, Konopleva M, Shi Y-X, et al Mutant FLT3: a direct target of sorafenib in acute myelogenous leukemia. J Natl Cancer Inst. 2008;100(3):184-198

30. Safaian NN, Czibere A, Bruns I, et al Sorafenib (Nexavar) induces molecular remission and regression of extramedullary disease in a patient with FLT3-ITD+ acute myeloid leukemia. Leukemia Res. 2009;33(2):348-350.

31. Metzelder S, Wang Y, Wollmer E, et al Compassionate use of sorafenib in FLT3ITD-positive acute myeloid leukemia: sustained regression before and after allogeneic stem cell transplantation. Blood. 200;113(26):6567-6571.

32. Metzelder SK, Schroeder T, Finck A, et al. High activity of sorafenib in FLT3-ITD-positive acute myeloid leukemia synergizes with allo-immune effects to induce sustained responses. Leukemia. 2012;26(11):23532359.

33. Metzelder SK, Schroeder T, Lübbert M, et al Long-term survival of sorafenib-treated FLT3-ITD-positive acute myeloid leukaemia patients relapsing after allogeneic stem cell transplantation. Eur J Cancer. 2017;86:233239.

34. Cortes JE, Khaled SK, Martinelli G, et al Efficacy and safety of single-agent quizartinib (Q), a potent and selective FLT3 inhibitor (FLT3i), in patients (pts) with FLT3internal tandem duplication (FLT3-ITD)mutated relapsed/refractory (R/R) acute myeloid leukemia (AML) enrolled in the global, phase 3, randomized controlled Quantum-R trial. Blood. 2018;132(Suppl 1):563-563.

35. Perl AE, Martinelli G, Cortes JE, et al. Gilteritinib or chemotherapy for relapsed or refractory FLT3-mutated AML. N Engl Med. 2019:381(18):1728-1740.

36. Baker SD, Zimmerman EI, Wang Y-D, et al. Emergence of polyclonal FLT3 tyrosine kinase domain mutations during sequential therapy with sorafenib and sunitinib in FLT3-ITD-positive acute myeloid leukemia. Clin Cancer Res. 2013;19(20):5758-5768.

37. Piloto O, Wright M, Brown P, Kim K-T, Levis M, Small D. Prolonged exposure to FLT3 inhibitors leads to resistance via activation of parallel signaling pathways. Blood. 2007;109(4):1643-1652.

38. Metzelder SK, Michel C, Bonin von M, et al NFATc1 as a therapeutic target in FLT3-ITDpositive AML. Leukemia. 2015;29(7):1470 1477

39. Pratz KW, Sato T, Murphy KM, Stine A, Rajkhowa T, Levis M. FLT3-mutant allelic burden and clinical status are predictive of response to FLT3 inhibitors in AML. Blood. 2010;115(7):1425-1432.

40. Smith CC, Levis MJ, Perl AE, et al. Emerging mutations at relapse in patients with FLT3mutated relapsed/refractory acute myeloid leukemia who received gilteritinib therapy in the phase 3 Admiral trial. Blood. 2019;134(Suppl 1):14.

41. Cortes JE, Khaled S, Martinelli G, et al. Quizartinib versus salvage chemotherapy in relapsed or refractory FLT3-ITD acute myeloid leukaemia (QuANTUM-R): a multicentre, randomised, controlled, open-label, phase 3 trial. Lancet Oncol. 2019;20(7):984997.

42. Röllig C, Serve H, Hüttmann A, et al. Addition of sorafenib versus placebo to standard therapy in patients aged 60 years or younger with newly diagnosed acute myeloid leukaemia (SORAML): a multicentre, phase 2, randomised controlled trial. Lancet Oncol. 2015;16(16):1691-1699.

43. Stone RM, Mandrekar SJ, Sanford BL, et al. Midostaurin plus chemotherapy for acute myeloid leukemia with a FLT3 mutation. N Engl J Med. 2017;377(5):454-464.

44. Huntly BIP, Shigematsu H, Deguchi K, et al. MOZ-TIF2, but not BCR-ABL, confers properties of leukemic stem cells to committed murine hematopoietic progenitors. Cancer Cell. 2004;6(6):587-596

45. Chu SH, Heiser D, Li L, et al. FLT3-ITD knockin impairs hematopoietic stem cell quiescence/homeostasis, leading to myeloproliferative neoplasm. Cell Stem Cell. 2012;11(3):346-358

46. Serve H, Krug U, Wagner R, et al. Sorafenib in combination with intensive chemotherapy in elderly patients with acute myeloid leukemia: results from a randomized, placebo-controlled trial. J Clin Oncol. 2013;31 (25):3110-3118

47. Hu $\mathrm{S}$, Niu $\mathrm{H}$, Inaba $\mathrm{H}$, Orwick $\mathrm{S}$, et al. Activity of the multikinase inhibitor sorafenib in combination with cytarabine in acute myeloid leukemia. J Natl Cancer Inst. 
2011:103(11):893-905

48. Ravandi F, Arana Yi C, Cortes JE, et al. Final report of phase II study of sorafenib, cytarabine and idarubicin for initial therapy in younger patients with acute myeloid leukemia. Leukemia. 2014;28(7):1543-1545.

49. Schlenk RF, Weber D, Fiedler W, et al. Midostaurin added to chemotherapy and continued single-agent maintenance therapy in acute myeloid leukemia with FLT3-ITD. Blood. 2019;133(8):840-851.

50. Wang ES, Tallman MS, Stone RM, et al. Low relapse rate in younger patients $\leq 60$ years old with newly diagnosed FLT3-mutated acute myeloid leukemia (AML) treated with crenolanib and cytarabine/anthracycline. Blood. 2016;128(22):1071.

51. Ravandi F, Alattar ML, Grunwald MR, et al. Phase 2 study of azacytidine plus sorafenib in patients with acute myeloid leukemia and FLT-3 internal tandem duplication mutation. Blood. 2013;121(23):4655-4662

52. Strati P, Kantarjian H, Ravandi F, et al. Phase I/II trial of the combination of midostaurin (PKC412) and 5-azacytidine for patients with acute myeloid leukemia and myelodysplastic syndrome. Am J Hematol. 2015;90(4):276281.

53. Swaminathan M, Kantarjian HM, Daver N, et al. The combination of quizartinib with azacitidine or low dose cytarabine is highly active in patients (Pts) with FLT3-ITD mutated myeloid leukemias: interim report of a phase I/II trial. Blood. 2017;130(Suppl 1):723.

54. Esteve J, Schots R, Del Castillo TB, et al. PS1065 open-label study of gilteritinib, gilteritinib plus azacitidine, or azacitidine alone in newly diagnosed FLT3-mutated AML patients ineligible for intensive chemotherapy: results from the safety cohort. HemaSphere. 2019;3(S1):482.

55. Larson RA, Mandrekar SJ, Sanford BL, et al. An analysis of maintenance therapy and post-midostaurin outcomes in the international prospective randomized, placebocontrolled, double-blind trial (CALGB 10603/RATIFY [Alliance]) for newly diagnosed acute myeloid leukemia patients with FLT3 mutations. Blood. 2017:130(Suppl 1):145.
56. Lee CJ, Savani BN, Mohty M, et al. Postremission strategies for the prevention of relapse following allogeneic hematopoietic cell transplantation for high-risk acute myeloid leukemia: expert review from the Acute Leukemia Working Party of the European Society for Blood and Marrow Transplantation. Bone Marrow Transplant. 2019;54(4):519-530.

57. Bornhäuser $M$, Illmer $T$, Schaich $M$, et al. Improved outcome after stem-cell transplantation in FLT3/ITD-positive AML. Blood. 2007;109(5):2264-2265; author reply 2265.

58. Pidala J, Martens M, Anasetti C, et al Factors associated with successful discontinuation of immune suppression after allogeneic hematopoietic cell transplantation. JAMA Oncol. 2019;6(1):e192974.

59. Kharfan-Dabaja MA, Labopin M, Polge E, et al. Association of second allogeneic hematopoietic cell transplant vs donor lymphocyte infusion with overall survival in patients with acute myeloid leukemia relapse. JAMA Oncol. 2018;4(9):1245-1253.

60. Mathew NR, Baumgartner F, Braun L, et al. Sorafenib promotes graft-versus-leukemia activity in mice and humans through IL-15 production in FLT3-ITD-mutant leukemia cells. Nat Med. 2018;24(3):282-291.

61. Yokoyama H, Lundqvist A, Su S, Childs R. Toxic effects of sorafenib when given early after allogeneic hematopoietic stem cell transplantation. Blood. 2010;116(15):28582859.

62. Maziarz RT, Levis M, Patnaik MM, et al. Midostaurin after allogeneic stem cell transplant in patients with FLT3-internal tandem duplication-positive acute myeloid leukemia. Bone Marrow Transplant. 2020 Dec 7 [Epub ahead of print]

63. Burchert A, Bug G, Fritz LV, et al. Sorafenib maintenance after allogeneic hematopoietic stem cell transplantation for acute myeloid leukemia with FLT3-internal tandem duplication mutation (SORMAIN). J Clin Oncol. 2020;38(26):2993-3002.

64. Xuan L, Wang Y, Huang F, et al. Sorafenib maintenance in patients with FLT3-ITD acute myeloid leukaemia undergoing allogeneic haematopoietic stem-cell transplantation: an open-label, multicentre, randomised phase 3 trial. Lancet Oncol. 2020;21(9):1201 1212

65. Walter RB, Gyurkocza B, Storer BE, et al Comparison of minimal residual disease as outcome predictor for AML patients in first complete remission undergoing myeloablative or nonmyeloablative allogeneic hematopoietic cell transplantation. Leukemia. 2015;29(1):137-144.

66. Araki D, Wood BL, Othus M, et al. Allogeneic hematopoietic cell transplantation for acute myeloid leukemia: time to move toward a minimal residual diseasebased definition of complete remission? Clin Oncol. 2016;34(4):329-336.

67. Levis M, Shi W, Chang K, et al. FLT3 inhibitors added to induction therapy induce deeper remissions. Blood. 2020;135 (1):75-78.

68. DiNardo CD, Jonas BA, Pullarkat V, et al Azacitidine and venetoclax in previously untreated acute myeloid leukemia. N Engl J Med. 2020;383(7):617-629.

69. Stein EM, DiNardo CD, Fathi AT, et al Molecular remission and response patterns in patients with mutant-IDH2 acute myeloid leukemia treated with enasidenib. Blood. 2019:133(7):676-687.

70. DiNardo CD, Stein EM, de Botton S, et al. Durable remissions with ivosidenib in IDH1-mutated relapsed or refractory AML N Engl J Med. 2018;378(25):2386-2398.

71. Wei AH, Döhner H, Pocock C, et al. The QUAZAR AML-001 maintenance trial results of a phase III international, randomized, double-blind, placebo-controlled study of CC-486 (oral formulation of azacitidine) in patients with acute myeloid leukemia (AML) in first remission. Blood. 2019;134 (Suppl 2):LBA-3.

72. Huls G, Chitu DA, Havelange V, et al Azacitidine maintenance after intensive chemotherapy improves DFS in older AML patients. Blood. 2019;133(13):14571464.

73. Gao L, Zhang Y, Wang S, et al. Effect of rhGCSF combined with decitabine prophylaxis on relapse of patients with high-risk MRDnegative AML after HSCT: an open-label, multicenter, randomized controlled trial. J Clin Oncol. 2020;38(36):1903277. 